\title{
GMR
}

\section{Anthropization as a determinant factor in the genetic structure of Copernicia prunifera (Arecaceae)}

\author{
L.G. Pinheiro, K.P.T. Chagas, A.S.M. Freire, M.C. Ferreira, \\ C.G. Fajardo and F.A. Vieira \\ Laboratório de Genética e Melhoramento Florestal, \\ Unidade Acadêmica Especializada em Ciências Agrárias, \\ Escola Agrícola de Jundiaí, Universidade Federal do Rio Grande do Norte, \\ Macaíba, RN, Brasil \\ Corresponding author: L.G. Pinheiro \\ E-mail: luciana.gpinheiro@yahoo.com.br \\ Genet. Mol. Res. 16 (3): gmr16039768 \\ Received June 29, 2017 \\ Accepted August 25, 2017 \\ Published September 27, 2017 \\ DOI http://dx.doi.org/10.4238/gmr16039768
}

Copyright $(2017$ The Authors. This is an open-access article distributed under the terms of the Creative Commons Attribution ShareAlike (CC BY-SA) 4.0 License.

ABSTRACT. This study uses ISSR molecular markers to characterize
the demographic pattern, and spatial genetic structure (SGS) at
different life stages of development (cohorts) in a natural population
of Copernicia prunifera in the Rio Grande do Norte State, Brazil. All
individuals were sampled and georeferenced in a 0.55 -ha plot. The
demographic analyses showed a clustered pattern in the first-distance
classes and a random or segregated pattern at higher distance classes
for all cohorts. Among the three studied life stages, juveniles showed
the greatest value for Nei's genetic diversity index $\left(H_{\mathrm{E}}=0.369\right)$, while
the lowest was found among reproductive adults $\left(H_{\mathrm{E}}=0.341\right)$. Greater
genetic differentiation was found within life stages $(98.61 \%)$ than
among stages $(1.39 \%)$. The total population $(\mathrm{N}=161)$ showed positive
and significant kinship in the first-distance class $(12.3 \mathrm{~m})$. The juveniles
showed significant kinship up to $10.5 \mathrm{~m}$. Non-reproductive adults had
a positive kinship in the first-distance class $(11.0 \mathrm{~m})$ and a random

Genetics and Molecular Research 16 (3): gmr16039768 
distribution of genotypes in the remaining classes, while reproductive adults showed a random spatial distribution of genotypes. Tests for genetic bottleneck showed that the number of loci with excess observed heterozygosity was greater than expected. The SGS results reflected the restricted seed dispersion of the species, and the genetic bottleneck reflected the reduction of genotypes as a result of the anthropization of C. prunifera natural environments.

Key words: Carnaúba; Molecular markers; Spatial pattern; Cohorts

\section{INTRODUCTION}

The spatial distribution of plant species is related to reproduction strategies, interactions between community members, and environmental factors (Borcard et al., 1992). However, in many cases there is a decreased density of individuals with increasing age due to the removal of individuals as a result of competition (Vieira et al., 2012), and can be the result of the interaction between biotic and abiotic factors that drive ecological processes (Condit et al., 2000). Spatial genetic structure (SGS) analysis enables a better understanding of genetic and ecological processes when working in forest populations (Vieira et al., 2010). SGS in natural populations is usually the result of a variety of factors, including limited dispersal of seeds and pollen, intraand interspecific competition, genetic drift, selection, and inbreeding (Hardy et al., 2006).

Through molecular techniques, inter- and intrapopulation genetic structure can be distinguished, allowing us to identify patterns of gene flow and dispersal (Cavers et al., 2005). As such, molecular markers are fundamental in analyzing patterns of SGS, characterizing natural plant populations, and estimating gene diversity, inbreeding, gene flow, and degree of kinship (Vieira and Carvalho, 2008; Gonçalves et al., 2010). Of the molecular markers available, ISSR (inter-simple sequence repeat) markers are commonly used in population genetic studies due to their ease of handling, the production of significant polymorphism, short turnaround time for results, and lower cost when compared to other markers (Brandão et al., 2015; Chagas et al., 2015). As such, several studies have used ISSR markers to evaluate the SGS of plant populations (Melo Júnior et al., 2015).

Despite there being few studies about seed and pollen dispersion of Copernicia prunifera, its main pollinators have been identified as the "marimbondo caboclo" wasp (Polistes canadensis Linnaeus) and the "irapuá" bee (Trigona spinipes Fabricius), while bats and the palm tanager "sanhaçu-do-coqueiro" (Tangara palmarum) are the main seed dispersers (Silva RAR, Fajardo CG, and Vieira FA, unpublished data; Vieira et al., 2015). However, the efficiency of these dispersal vectors for $C$. prunifera is not yet well established, and natural populations of the species continue to be subjected to extensive anthropogenic pressures. Since large quantities of fruit are dispersed near to parent trees, as is generally the case in tropical species (Condit et al., 2000; Defavari et al., 2009), a more significant SGS is expected in earlier developmental stages than among adults, and previous research has shown differences in the magnitude of SGS between different life stages (Ng et al., 2004; Vieira et al., 2012). Furthermore, processes of anthropization, while contributing directly to population reduction, can also affect dispersers and pollinators, which may influence the diversity and genetic structure of the population. In this context, the present study aimed to assess the distribution pattern and SGS in a natural population of C. prunifera individuals at different developmental stages.

Genetics and Molecular Research 16 (3): gmr16039768 


\section{MATERIAL AND METHODS}

\section{Study species}

C. prunifera (Arecaceae), commonly known as "carnaúba", is native to northeastern Brazil and can be found in flood plains of lowland river valleys across the States of Piauí, Ceará, Rio Grande do Norte, Maranhão, Bahia, Alagoas, and Sergipe (Leitman et al., 2015). Besides their potential in urban landscaping (i.e., urban forestry, flower beds, and squares), the species is a source of raw material for various industries. While its leaves are used as animal feed and as raw material for artisanal products, the most important resources are waxes extracted from the leaves that are used for a variety of purposes, such as the production of drug capsules, food products, floor polishing waxes, and electronic components.

\section{Study site and sampling}

The study was carried out in the municipality of São Miguel do Gostoso, Rio Grande do Norte State, approximately $102 \mathrm{~km}$ from the state capital. It has a tropical climate with a dry season (As), according to the Köppen-Geiger climate classification, and soils in the region are Dystrophic Quartz Sands (IDEMA, 2010). All C. prunifera individuals across three developmental stages (juvenile, non-reproductive adults, and reproductive adults) were sampled in a defined plot measuring $50 \mathrm{~m}$ (East-West) x $110 \mathrm{~m}$ (North-South) at $5^{\circ} 07^{\prime} 20^{\prime \prime} \mathrm{S}$ and $35^{\circ} 41^{\prime} 04^{\prime \prime} \mathrm{W}$. We recorded the geographical positions ( $\mathrm{x}$ and $\mathrm{y}$ ) of all individuals with the aid of a measuring tape (Figure 1).

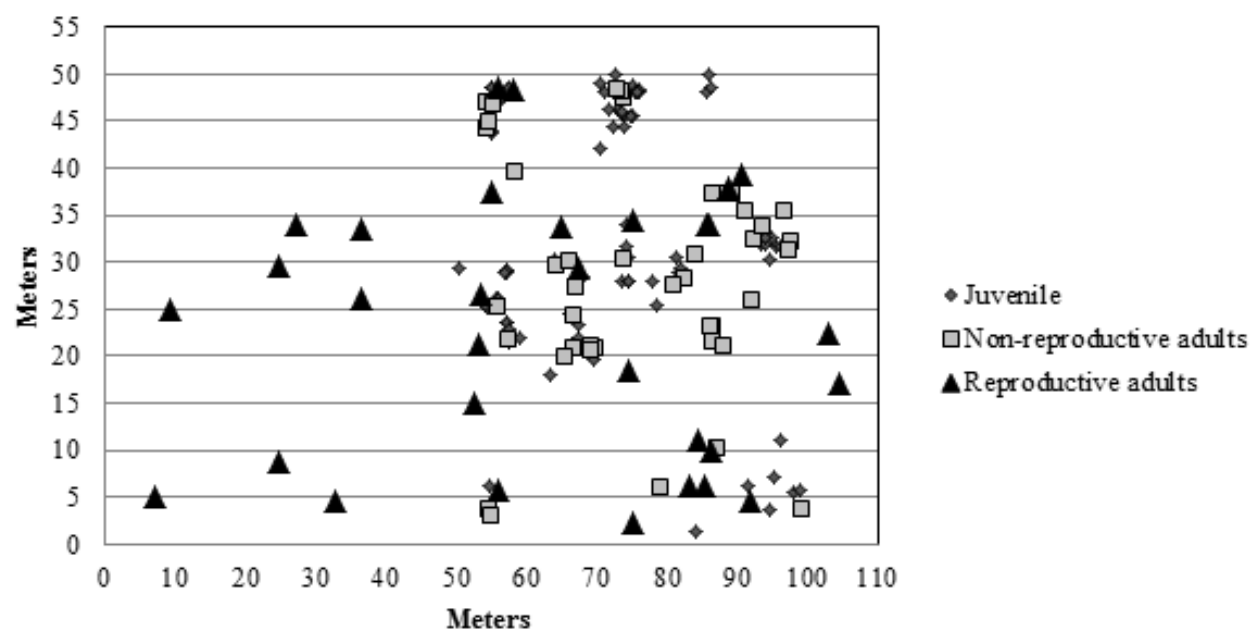

Figure 1. Spatial distribution of Copernicia prunifera individuals in a natural population in the municipality of São Miguel do Gostoso, RN, Brazil.

The developmental stages of $C$. prunifera individuals were determined based on height and reproductive status. Individuals up to $1.70 \mathrm{~m}$ in height were considered juveniles, while the other two classes were determined based on the incidence of reproductive events (flowering and fruiting) at the time of analysis. The average height of non-reproductive adults

Genetics and Molecular Research 16 (3): gmr16039768 
was 3.60 and $5.85 \mathrm{~m}$ for reproductive adults (Table 1). Leaf samples were collected from all individuals, placed in labeled microtubes containing $1 \mathrm{~mL} 2 \mathrm{X}$ CTAB extraction buffer (cationic hexadecyltrimethylammonium bromide), and stored in a freezer at $-20^{\circ} \mathrm{C}$.

\section{DNA isolation, polymerase chain reaction (PCR), and electrophoresis}

DNA extraction was conducted based on the CTAB method described by Doyle and Doyle (1987). The amplification of DNA fragments was performed by PCR using a Veriti 96well thermal cycler. The PCR solution consisted of an IC PHT ${ }^{\mathrm{TM}}$ pre-mix at a concentration of $1 \mathrm{X}$ containing IC buffer $(50 \mathrm{mM} \mathrm{KCl}, 10 \mathrm{mM}$ Tris-HCl, $\mathrm{pH}$ 8.4, 0.1 TritonX-100, 2.0 $\mathrm{mM} \mathrm{MgCl}_{2}$ ), nucleotides (dATP, dCTP, dGTP, dTTP), and thermostable enzyme Taq DNA Polymerase (recombinant), primer, DNA, and ultrapure water. The PCR cycle consisted of denaturation at $94^{\circ} \mathrm{C}$ for $2 \mathrm{~min}$, followed by 37 cycles at $94^{\circ} \mathrm{C}$ for $15 \mathrm{~s}, 47^{\circ} \mathrm{C}$ for $30 \mathrm{~s}$, and $72^{\circ} \mathrm{C}$ for $1 \mathrm{~min}$. The process was finalized at $72^{\circ} \mathrm{C}$ for $7 \mathrm{~min}$ and cooled to $4^{\circ} \mathrm{C}$.

PCR products were stained with GelRed ${ }^{\mathrm{TM}}$ and subjected to electrophoresis on $1.5 \%$ agarose gel $(\mathrm{v} / \mathrm{v})$ in 1.0X TAE buffer (EDTA Tris-acetate). The total electrophoresis reaction time was $2.5 \mathrm{~h}$ at $100 \mathrm{~V}$. We used a molecular weight marker (ladder) of 10,000 bp. After electrophoresis, gels were photographed with E-Box VX2 equipment in ultraviolet light. Gels were analyzed for presence (1) and absence (0) of fragments, with each amplified fragment considered a locus. Based on these results, a binary matrix was constructed to carry out the statistical analyses.

\section{Data analysis}

\section{Spatial pattern}

To determine the spatial distribution pattern of the species, we used the SpPack 1.38 program, with the second-order univariate function of neighbor density or NDF (neighborhood density function) (Condit et al., 2000). We assessed the entire population together and separately for each stage of development. Simulations were performed using distance classes $(\mathrm{t})$ between 1 and $110 \mathrm{~m}$, with intervals of $10 \mathrm{~m}$ for the total population and reproductive adults, and $5 \mathrm{~m}$ for juveniles and non-reproductive adults to avoid the occurrence of jagged plots (Wiegand and Moloney, 2004). We also corrected for edge effect based on Goreaud and Pélissier (1999). Using the values obtained in the NDF statistic ( $\mathrm{t}$ ), correlograms were constructed as a function of the distance $t$ and compared to confidence intervals (upper and lower) obtained from 499 Monte Carlo random simulations (alpha $=0.01$ ).

Three statistical hypotheses were tested: 1) Complete random spatial distribution (null hypothesis): NDF values within the range of confidence intervals; 2) Aggregate pattern (alternate hypothesis 1): NDF values above the upper confidence interval; and 3) Segregated pattern (alternate hypothesis 2): NDF values below the lower confidence interval.

\section{Genetic diversity and polymorphic information content (PIC) value}

The genetic variation for each developmental stage within the population was assessed using the POPGENE program version 1.3 (Yeh et al., 1997), based on the following parameters: number of observed alleles $\left(N_{\mathrm{A}}\right)$, number of effective alleles $\left(N_{\mathrm{E}}\right)$, Nei's genetic diversity $\left(H_{\mathrm{E}}\right)$, and Shannon index $(I)$.

Genetics and Molecular Research 16 (3): gmr16039768 
The PIC was calculated to test the effectiveness of the markers to detect polymorphism between individuals, with the presence or absence of loci used as indicators. We used the formula proposed by Anderson et al. (1993):

$$
P I C_{i}=1-\sum_{j=1}^{n} P_{i j}^{2}
$$

where Pij is the frequency of allele $j$ in marker $i$. According to Botstein et al. (1980), markers are classified as satisfactory in informative content when the PIC value is above 0.5 ; moderately informative when the value varies between 0.25 and 0.5 ; and with limited information value when below 0.25 .

\section{Population genetic structure}

Analysis of molecular variance (AMOVA) was used to determine the genetic structure between the different developmental stages, with the ARLEQUIN 3.1 program. The significance level was obtained by the permutation test $(\mathrm{N}=10,000)$ (Excoffier et al., 1992). Using this analysis, we estimated population differentiation from molecular data and hypothesis tests.

\section{Spatial genetic structure}

For the analysis of SGS, we estimated the coancestry value between pairs of individuals at different distance classes for each development stage and the entire population (Hardy, 2003), using the SPAGeDi 1.2 program (Hardy and Vekemans, 2002). The intensity of SGS at different development stages was calculated using the $S p$ statistic, based on the formula:

$$
S p=-b_{\log } /\left(1-F_{i j(1)}\right)
$$

where $-b_{\log }$ is the slope of the regression curve of the coancestry coefficient, and $F_{\mathrm{ij}(1)}$ is the measure of the coancestry coefficient of the first-distance class $\left(F_{\mathrm{ij}}\right)$.

\section{Detection of genetic bottlenecks}

To identify a reduction in effective population size, we used the Bottleneck program version 1.2 (Cornuet and Luikart, 1996) and the infinite allele model (IAM) and the stepwise mutation model (SMM). These models were used to calculate the expected heterozygosity of the population at mutation-drift equilibrium and compare it with actual heterozygosity. For ISSR loci, the mutation model is intermediate between IAM and SMM, so both models were used. To identify significant genetic bottlenecks, the sign test was used $(\alpha=0.05)$ based on allele frequencies (Cornuet and Luikart, 1996).

\section{RESULTS}

\section{Demographic structure}

Of the 161 individuals sampled, 88 were classified as juveniles (height between 0.10 
and $1.70 \mathrm{~m}$ ), 42 as non-reproductive adults (height greater than $1.70 \mathrm{~m}$ and no reproductive events), and 31 as reproductive adults (Table 1).

Table 1. Ontogenetic characterization based on height and incidence of reproductive events for Copernicia prunifera.

\begin{tabular}{l|c|c}
\hline Classes & Number of individuals & Mean height (m) \pm SD \\
\hline Juveniles & 88 & $1.14 \pm 0.41$ \\
\hline Non-reproductive adults & 42 & $3.60 \pm 2.09$ \\
\hline Reproductive adults & 31 & $5.85 \pm 0.95$ \\
\hline Total & 161 & $2.69 \pm 2.21$ \\
\hline
\end{tabular}

$\mathrm{SD}=$ standard deviation.

Considering the entire population, the spatial pattern of $C$. prunifera showed aggregation at distance classes less than $40 \mathrm{~m}$, indicating acceptance of the alternative hypothesis of aggregation. At distances between 40 and $50 \mathrm{~m}$, the spatial pattern was random, accepting the null hypothesis, and at distances greater than $50 \mathrm{~m}$, we observed a segregated pattern, indicating the acceptance of the alternative hypothesis of segregation (Figure 2a).

Considering only juvenile individuals, the spatial pattern showed aggregation in a radius of up to $5 \mathrm{~m}$, mainly within the first $2 \mathrm{~m}$, therefore, accepting the alternative hypothesis of aggregation. At distances greater than $5 \mathrm{~m}$, the pattern varied between random, aggregate and segregated, but with lower density (Figure 2b).

For non-reproductive adults, we found that up to $4 \mathrm{~m}$ the density of neighbors was greater than expected; thus, the aggregation hypothesis was accepted. At distances greater than $5 \mathrm{~m}$, the pattern was random, thus accepting the null hypothesis of a random distribution (Figure 2c).

For reproductive adults, at a distance of up to $5 \mathrm{~m}$, the spatial pattern was aggregate, and after this distance, it became random, thus accepting the hypothesis of aggregation and random distribution, respectively (Figure 2d).
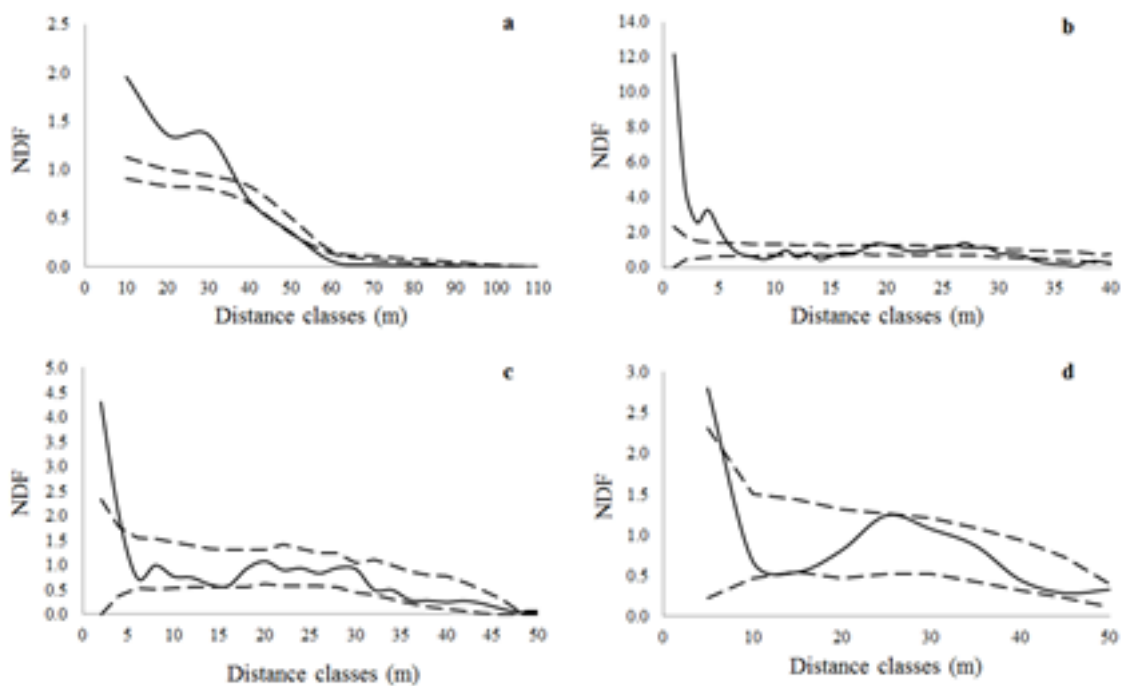

Figure 2. Spatial distribution pattern obtained through univariate analysis of the neighborhood density (NDF) of Copernicia prunifera individuals: all developmental stages (a); juveniles (b); non-reproductive adults (c); and reproductive adults (d). Dotted lines correspond to the upper and lower confidence intervals.

Genetics and Molecular Research 16 (3): gmr16039768 


\section{Genetic diversity and PIC value}

The eight primers used generated a total of 102 loci, of which 100 were polymorphic (98.04\%). The number of bands ranged from 10 to 17, with a mean of 12.75 loci per primer. The primers UBC 825, UBC 840, and UBC 873 produced the greatest number of loci. The PIC values for each primer varied between 0.455 and 0.500 (Table 2).

Table 2. Nucleotide sequence of the ISSR primers, average number of loci, and PIC value of each primer.

\begin{tabular}{|c|c|c|c|}
\hline Primer ISSR & Sequence $\left(5^{\prime}-3^{\prime}\right)$ & Loci number & PIC \\
\hline $\mathrm{UBC} 825(\mathrm{AC})_{8}-\mathrm{T}$ & ACA CAC ACA CAC ACA CT & 17 & 0.477 \\
\hline UBC $827(\mathrm{AC}) 8-\mathrm{G}$ & ACA CAC ACA CAC ACA CG & 10 & 0.455 \\
\hline UBC $840(\mathrm{GA})_{8}-\mathrm{YT}$ & GAG AGA GAG AGA GAG AYT & 14 & 0.499 \\
\hline UBC $851(\mathrm{GT})_{8}-\mathrm{YG}$ & GTG TGT GTG TGT GTG TYG & 12 & 0.469 \\
\hline UBC 857 (AC)8-YG & ACA CAC ACA CAC ACA CYG & 12 & 0.500 \\
\hline UBC 859 (TG) $)_{8}-\mathrm{RC}$ & TGT GTG TGT GTG TGT GRC & 13 & 0.497 \\
\hline UBC $860(\mathrm{TG})_{8}-\mathrm{RA}$ & TGT GTG TGT GTG TGT GRA & 10 & 0.489 \\
\hline UBC $873(\mathrm{GACA})_{4}$ & GAC AGA CAG ACA GAC A & 14 & 0.485 \\
\hline Mean & & 12.75 & 0.484 \\
\hline
\end{tabular}

$\mathrm{R}=$ purine $(\mathrm{A}$ or $\mathrm{G})$ and $\mathrm{Y}=$ pyrimidine $(\mathrm{C}$ or $\mathrm{T})$.

For the total population, the $N_{\mathrm{A}}$ was 1.980 , and $N_{\mathrm{E}}$ was 1.654 . The $H_{\mathrm{E}}$ was 0.370 , and $I$ was 0.543 (Table 3).

Table 3. Measures of genetic diversity for different developmental stages of Copernicia prunifera.

\begin{tabular}{l|c|c|c|c|c|c}
\hline Classes & $\mathrm{N}$ & Polymorphic loci (\%) & $N_{\mathrm{A}}$ & $N_{\mathrm{E}}$ & $H_{\mathrm{E}}$ & $I$ \\
\hline Juveniles & 88 & $99 / 97.06$ & $1.971 \pm 0.018$ & $1.657 \pm 0.033$ & $0.369 \pm 0.015$ & $0.541 \pm 0.019$ \\
\hline Non-reproductive adults & 42 & $93 / 91.18$ & $1.912 \pm 0.043$ & $1.626 \pm 0.051$ & $0.353 \pm 0.024$ & $0.517 \pm 0.032$ \\
\hline Reproductive adults & 31 & $96 / 94.12$ & $1.941 \pm 0.042$ & $1.591 \pm 0.058$ & $0.341 \pm 0.027$ & $0.505 \pm 0.036$ \\
\hline Total & 161 & $100 / 98.04$ & $1.980 \pm 0.0109$ & $1.654 \pm 0.0244$ & $0.370 \pm 0.0110$ & $0.543 \pm 0.0139$ \\
\hline
\end{tabular}

$N_{\mathrm{A}}=$ observed number of alleles; $N_{\mathrm{E}}=$ effective number of alleles; $H_{\mathrm{E}}=$ Nei's genetic diversity index; $I=$ Shannon index. Values are reported as means \pm standard error.

Among the three developmental stages, the greatest percentage of polymorphic loci was found in juveniles $(97.06 \%)$. The lowest percentage of polymorphic loci was observed in non-reproductive adults $(91.18 \%)$. The $N_{\mathrm{A}}$ and the $N_{\mathrm{E}}$ were also higher for juveniles, with values of 1.971 and 1.657, respectively, and juveniles also presented the highest $H_{\mathrm{E}}(0.369)$ (Table 3). The lowest $H_{\mathrm{E}}$ was found among reproductive adults, at 0.341 . Juveniles showed the greatest genetic variability, with a value of $0.541(I)$, and reproductive adults showed the lowest genetic variability, with 0.505 (I) (Table 3).

\section{Genetic structure}

The results of AMOVA showed greater genetic diversity within development stages (98.61\%) than among stages (1.39\%) (Table 4).

Genetics and Molecular Research 16 (3): gmr16039768 
Table 4. Analysis of molecular variance for the total population and between developmental stages for Copernicia prunifera.

\begin{tabular}{l|c|c|c|c|c}
\hline Source of variation & d.f. & SQ & Variance components & Variation percentage & P \\
\hline Among developmental stages & 2 & 12.852 & 0.05404 & 1.39 & 0.071 \\
\hline Within developmental stages & 158 & 605.570 & 3.83272 & 98.61 & \\
\hline Total & 160 & 618.422 & 3.88677 & & \\
\hline Fixation index Fst: & 0.01390 & & & & \\
\hline
\end{tabular}

d.f. $=$ degrees of freedom; $S Q=$ sum of squares of deviations.

\section{Spatial genetic structure}

The total population $(\mathrm{N}=161)$ presented a positive and significant kinship in the first-distance class $(12.3 \mathrm{~m}$ ) (Figure 3a). Juveniles presented a significant kinship up to 10.5 $\mathrm{m}$ and a negative kinship in the fifth distance class $(37.6 \mathrm{~m})$ (Figure $3 \mathrm{~b}$ ). Non-reproductive adults showed a positive kinship in the first-distance class $(11.0 \mathrm{~m})$ and a random distribution of genotypes in the other classes (Figure 3c). Reproductive adults presented a random spatial distribution of genotypes (Figure 3d).

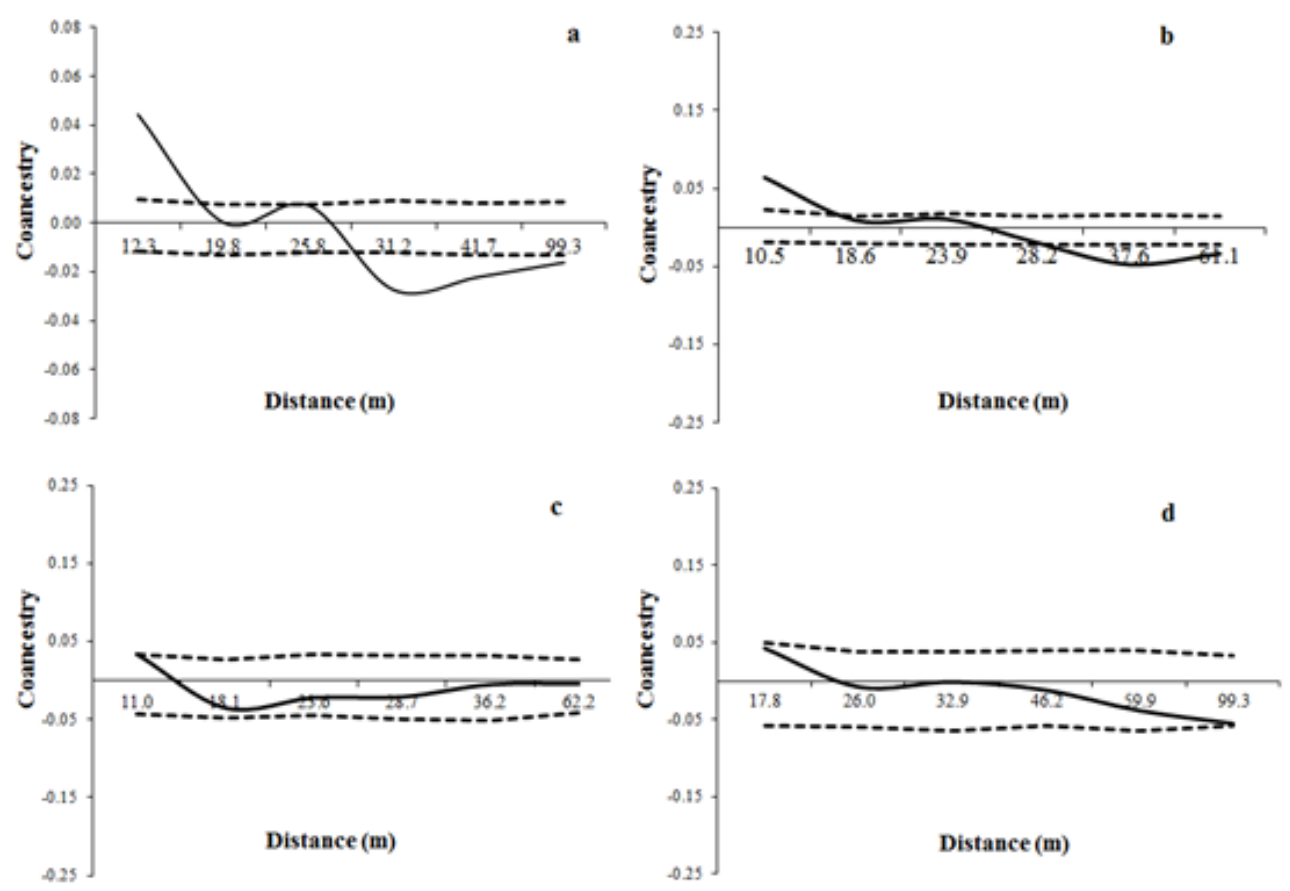

Figure 3. Correlograms of coancestry coefficients for the total population (a), juveniles (b), non-reproductive adults (c), and reproductive adults (d) of Copernicia prunifera.

The $S p$ statistic showed the occurrence of genetic structuring for the total population, juveniles, and the adult reproductive stages $(\mathrm{P}<0.05)$, whereas among non-reproductive adults, no structuring was observed $(\mathrm{P}>0.05)$ (Table 5).

Genetics and Molecular Research 16 (3): gmr16039768 
Table 5. Spatial genetic structure of Copernicia prunifera for the total population and each developmental stage.

\begin{tabular}{l|c|c|c|c|c|c}
\hline Classes & $\mathrm{N}$ & $F_{i j}$ & $B_{\log }$ & $S p$ & SE & $\mathrm{P}$ \\
\hline Juveniles & 88 & 0.064 & -0.046 & 0.046 & 0.005 & 0.000 \\
\hline Non-reproductive adults & 42 & 0.034 & -0.016 & 0.016 & 0.007 & 0.143 \\
\hline Reproductive adults & 31 & 0.043 & -0.039 & 0.039 & 0.006 & 0.017 \\
\hline Total & 161 & 0.044 & -0.034 & 0.034 & 0.003 & 0.000 \\
\hline
\end{tabular}

$\mathrm{N}$ is the number of individuals sampled, $F_{i j}$ is the coancestry coefficient for the first-distance class, $B_{l o g}$ is the slope of the regression curve of the coancestry coefficient, $S p$ is the $S p$ statistic, SE is the standard error, and P the significance value.

\section{Genetic bottlenecks}

In both the IAM and SMM models, the number of loci with observed excess heterozygosity was greater than expected and significantly based on the sign test $(\mathrm{P}<0.0001)$ (Table 6).

Table 6. Tests between mutation and genetic drift for the Copernicia prunifera population using the IAM and SMM models.

\begin{tabular}{l|c|c|c}
\hline Models & $\mathrm{N}$ & $H_{\mathrm{E}}$ & $\mathrm{P}$ \\
\hline IAM & 39.28 & 92.0 & $0.00000^{*}$ \\
\hline SMM & 45.26 & 87.0 & $0.00000^{*}$ \\
\hline
\end{tabular}

$\mathrm{N}=$ expected number of loci with excess heterozygosity based on the respective model; $H_{\mathrm{E}}=$ number of loci with excess heterozygosity; $\mathrm{P}=$ probability; *significant at $5 \%$ probability.

\section{DISCUSSION}

\section{Demographic structure}

A greater number of individuals in early developmental stages may indicate the existence of strategies that aid in the survival of the species. Similarly, a lower number of individuals in the final stages of development may be influenced by biotic and abiotic factors, such as seed dispersal, competition, and soil type (Vieira et al., 2012). Similar results were found by Alves et al. (2011) in a study with Syagrus pseudococos (Raddi) Glassman (Arecaceae) in which they found an aggregate spatial pattern, mainly in the initial developmental stages. González et al. (2012), in a study of an Iriartea deltoidea Ruiz \& Pav. Palm population also found a greater number of individuals at early stages of development, and reduced density with increasing age, typical of natural tropical plant populations.

The occurrence of adults without the presence of young individuals in the immediate vicinity is likely related to anthropogenic activities at the site, which may compact the soil and prevent the establishment of seedlings. However, the presence of juvenile individuals and non-reproductive adults without nearby reproductive adults may be related to a lack of reproductive events at the time of collection or the removal of the mother plant from the site.

In this study, the aggregate spatial distribution pattern found predominately in the firstdistance classes may be related to restricted seed dispersal near to the mother plants. Similar results were reported by Silva et al. (2014) in a study with $C$. prunifera carried out in the municipality of Lagoa de Pedras, RN, and the authors suggest that the aggregate distribution pattern in the first-distance classes is related to restricted dispersion around parent trees. Vieira

Genetics and Molecular Research 16 (3): gmr16039768 
et al. (2010), working with Euterpe edulis Martius (Arecaceae), also suggest that the aggregate distribution in the first-distance classes relates to the dispersion of seeds near to parental plants.

The fluctuation between aggregate, random, and segregated patterns, especially among juveniles, may be related to the fact that palm trees often present heterogeneous spatial distribution due to environmental changes, such as increased exploitation, and the influence of dispersal vectors (Fragoso et al., 2003).

\section{Genetic diversity and PIC value}

The high percentage of polymorphic loci found herein demonstrates the effectiveness of the ISSR primers in assessing genetic diversity in natural populations of $C$. prunifera. Rossi et al. (2014) also reported high polymorphism (78.3\%) in natural populations of Mauritia flexuosa L.f. (Arecaceae) using ISSR primers; however, their results were lower than those found in the present study.

The genetic diversity observed between developmental stages and between individuals can be related to environmental disturbances, restricted seed dispersal, and low density of reproductive individuals (Vieira et al., 2012). The low levels of genetic variability found in reproductive and non-reproductive adults may be related to human interference in the area and resulting environmental modification (Gonçalves et al., 2010), which is also supported by the tests for genetic bottleneck (Table 6).

In the study area, we observed evidence of trampling, and also the cutting of trees, probably for firewood, which suggests the occurrence of anthropization. The area was further affected by the construction of a wind farm near to the study population. However, the most significant impact on the studied population is likely the harvesting and extraction of $C$. prunifera. Due to its many uses in industry and commerce, the species is heavily exploited, often in a predatory manner, causing population decline.

A decrease in the effective population size contributes to a decrease in gene flow, reducing the number of alleles and heterozygosity, and leading to a reduction in diversity within populations (Defavari et al., 2009). Thus, the diversity indices are related to the level of conservation and the demographic structure of the population.

In a study conducted with a population of E. edulis using allozyme markers, Conte et al. (2003) found genetic variability within developmental stages and no significant differences in the genetic diversity index among the analyzed stages. The authors suggest that this may be related to large numbers of adult individuals in the studied population, which would help to counter the effects of genetic drift.

According to the classification of molecular marker effectiveness described by Botstein et al. (1980), all primers used in the present study can be considered moderately informative since they present PIC values ranging from 0.455 to 0.500 . In a study on Euterpe oleracea Mart. (Arecaceae) using microsatellite markers, Oliveira et al. (2010) obtained PIC values ranging from 0.60 to 0.86 , values that exceed the primers used in the present study. However, Brandão et al. (2015), using ISSR markers to analyze Myrcia splendens (SW.) DC. (Myrtaceae), found PIC values between 0.305 and 0.464 , which are similar to the results discussed herein.

\section{Genetic structure}

We found greater genetic diversity within developmental stages than between stages

Genetics and Molecular Research 16 (3): gmr16039768 
which can be explained mainly by mutation, natural, and artificial selection (anthropogenic activities), and genetic drift, among other mechanisms that bring about changes in genetic structure and affect the reproduction patterns of plants (Lowe et al., 2005; Eckert et al., 2010). Thus, the genotypic structure of our studied population may be related to exploitation of the species in the area that can interfere with the genetic basis and mechanisms linked to genetic structure. Similar results were also described by Conte et al. (2003) in a study on a population of E. edulis, in which the authors suggest that the exploitation of the species influences genotypes in the studied population.

\section{Spatial genetic structure}

The positive and significant kinship found in the first-distance class of the total population $(12.3 \mathrm{~m})$ is similar to the results found by Vieira et al. (2010) in a study with the palm tree E. edulis, in which they reported positive coancestry up to $15 \mathrm{~m}$. These results indicate an increase in the genetic structure among nearby individuals. Choo et al. (2012) analyzing the Attalea phalerata Mart. ex Spreng. Palm also found a positive kinship in the first-distance classes at different stages of development. The authors suggest that the significant SGS found in their study is related to short-distance seed dispersal.

In a study on M. splendens in fragments and vegetation corridors using ISSR primers, Brandão et al. (2011) reported the occurrence of positive coancestry in two corridors at distances of $27(\mathrm{P}=0.029)$ and $70 \mathrm{~m}(\mathrm{P}=0.009)$, based on the results of the $S p$ statistic. Meanwhile, Silva et al. (2011) studying two populations of Geonoma schottiana Mart. (Arecaceae) using isoenzymes, noted the absence of genetic structure in one population, while the other showed a weak and non-significant structure, with the $S p$ value equal to 0.006 .

Thus, the SGS results found in this study may be related to both restricted seed dispersal (Silva et al., 2014) and anthropogenic disturbances at the site. These influences tend to reduce population size and consequently increase self-fertilization rates and mating between related individuals, which may lead to a loss of reproductive capacity over generations (Gonçalves et al., 2010).

\section{Genetic bottlenecks}

The results found in the tests for genetic bottleneck can be explained by the reduction of genotypes caused by the anthropization of the study area. As a management strategy, these results may support the implementation of subsidies for the genetic conservation of the species in extractive communities. Chagas et al. (2015) have suggested that the reduction of the population size of Elaeis guineensis Jacq. (Arecaceae) is due to a loss of habitat and increased agricultural activities at the study site.

The random demographic distribution found in the higher distance classes of $C$. prunifera may be related to species exploitation. The intense exploitation of the species observed in the study area results in population decrease and fragmentation, which also leads to reductions in genetic diversity.

\section{Conclusions and implications for conservation}

The aggregate spatial distribution pattern presented by C. prunifera individuals showed a greater density of neighbors in the first-distance classes. Besides, there was a positive

Genetics and Molecular Research 16 (3): gmr16039768 
and significant kinship between individuals in the first-distance class for the total population. Among the developmental stages, the greatest genetic variability was found for juveniles, and we found a greater genetic diversity within developmental stages than among stages. In addition to the biotic factor identified herein (restricted seed dispersal), the exploitation of $C$. prunifera is a likely determinant of the spatial genetic pattern found.

Loss of native vegetation and habitat fragmentation are major threats to biodiversity, which lead to a loss of genetic variability in plant populations (Kageyama et al., 1998). Information generated by population genetic studies are important in the development of breeding and conservation programs as they help to define areas that are priorities for conservation and resource management (Kageyama et al., 1998). Although C. prunifera is not included on the list of endangered species, agricultural and extraction activities have significantly reduced natural populations of the species throughout its range (Reis et al., 2011), as can be seen in the study area through the harvesting of individuals and the construction of a nearby wind farm. Such factors can directly affect population reduction, while also having an impact on pollination and dispersion of fruits.

Based on our results, further studies should be carried out in different populations of C. prunifera. More information is needed on the reproductive biology and the pollen and seed dispersal of the species since these factors have an impact on its genetic structure and diversity.

In the present study, we observed genetic structuring among individuals located close to each other, which may be related to restricted seed dispersal or anthropization at the study site. These factors can affect the species' reproduction patterns, resulting in mating between related individuals and a further loss of reproductive capacity. Thus, there is a need for conservation of natural populations of $C$. prunifera so that its genetic variability does not disappear in subsequent generations.

\section{Conflicts of interest}

The authors declare no conflict of interest.

\section{ACKNOWLEDGMENTS}

The authors acknowledge Programa de Pós-Graduação em Ciências Florestais, UFRN (PPGCFL/UFRN) and Conselho Nacional de Desenvolvimento Científico e Tecnológico (CNPq), for financial support (Process \#471099/2012-0). We also thank Dr. Evelyn R. Nimmo for editing the English language of the manuscript.

\section{REFERENCES}

Alves I, Fisch STV, Mendonça CBG and Monteiro EA (2011). Distribuição e padrão espacial da Palmeira Syagrus pseudococos (Raddi) Glassman (Arecaceae), em um trecho de encosta na Serra do Mar, Ubatuba-SP, Brasil. Rev. Biociênc. Univ. Taubaté 17: 52-59.

Anderson JA, Churchill GA, Autrique JE, Tanksley SD, et al. (1993). Optimizing parental selection for genetic linkage maps. Genome 36: 181-186.

Borcard D, Legendre P and Drapeau P (1992). Partialling out the spatial component of ecological variation. Ecology 73 : 1045-1055. https://doi.org/10.2307/1940179

Botstein D, White RL, Skolnick M and Davis RW (1980). Construction of a genetic linkage map in man using restriction fragment length polymorphisms. Am. J. Hum. Genet. 32: 314-331.

Genetics and Molecular Research 16 (3): gmr16039768 
Brandão MM, Vieira FA and Carvalho D (2011). Estrutura genética em microescala espacial de Myrcia splendens (Myrtaceae). Rev. Arvore 35: 957-964. https://doi.org/10.1590/S0100-67622011000600001

Brandão MM, Vieira FA, Nazareno AG and Carvalho D (2015). Genetic diversity of Neotropical tree Myrcia splendens (Myrtaceae) in a fragment-corridor system in the Atlantic rainforest. Flora 216: 35-41. https://doi.org/10.1016/j. flora.2015.07.006

Cavers S, Degen B, Caron H, Lemes MR, et al. (2005). Optimal sampling strategy for estimation of spatial genetic structure in tree populations. Heredity (Edinb) 95: 281-289. https://doi.org/10.1038/sj.hdy.6800709

Chagas KPT, Sousa RF, Fajardo CG and Vieira FA (2015). Seleção de marcadores ISSR e diversidade genética em uma população de Elaeis guineensis. Agraria 10: 147-152. https://doi.org/10.5039/agraria.v10i1a5133

Choo J, Juenger TE and Simpson BB (2012). Consequences of frugivore-mediated seed dispersal for the spatial and genetic structures of a neotropical palm. Mol. Ecol. 21: 1019-1031. https://doi.org/10.1111/j.1365-294X.2011.05425.X

Condit R, Ashton PS, Baker P, Bunyavejchewin S, et al. (2000). Spatial patterns in the distribution of tropical tree species. Science 288: 1414-1418. https://doi.org/10.1126/science.288.5470.1414

Conte R, Nodari RO, Vencovsky R and dos Reis MS (2003). Genetic diversity and recruitment of the tropical palm, Euterpe edulis Mart., in a natural population from the Brazilian Atlantic Forest. Heredity (Edinb) 91: 401-406. https://doi.org/10.1038/sj.hdy.6800347

Cornuet JM and Luikart G (1996). Description and power analysis of two tests for detecting recent population bottlenecks from allele frequency data. Genetics 144: 2001-2014.

Defavari GR, Tarazi R, Moreno MA, Ferraz EM, et al. (2009). Estrutura genética espacial intrapopulacional de Hymenaea stigonocarpa Mart. Ex Hayne na Estação Ecológica de Itirapina, SP. Sci. For. 37: 089-098.

Doyle JJ and Doyle JL (1987). Isolation of plant DNA from fresh tissue. Focus 12: 13-15.

Eckert CG, Kalisz S, Geber MA, Sargent R, et al. (2010). Plant mating systems in a changing world. Trends Ecol. Evol. (Amst.) 25: 35-43. https://doi.org/10.1016/j.tree.2009.06.013

Excoffier L, Smouse PE and Quattro JM (1992). Analysis of molecular variance inferred from metric distances among DNA haplotypes: application to human mitochondrial DNA restriction data. Genetics 131: 479-491.

Fragoso JMV, Silvius KM and Correa JA (2003). Long-distance seed dispersal by tapirs increases seed survival and aggregates tropical trees. Ecology 84: 1998-2006. https://doi.org/10.1890/01-0621

Gonçalves AC, Reis CAF, Vieira FA and Carvalho D (2010). Estrutura genética espacial em populações naturais de Dimorphandra mollis (Fabaceae) na região norte de Minas Gerais, Brasil. Rev. Bras. Bot. Braz. J. Bot. 33: 325-332. https://doi.org/10.1590/S0100-84042010000200013

González MR, Parrado-Rosselli A and López-Camacho R (2012). Estructura poblacional de la palma Iriartea deltoidea, en un bosque de tierra firme de la amazonia colombiana. Caldasia 34: 187-204.

Goreaud F and Pélissier R (1999). On explicit formulas of edge effect correction for Ripley’s K-function. J. Veg. Sci. 10: 433-438. https://doi.org/10.2307/3237072

Hardy OJ (2003). Estimation of pairwise relatedness between individuals and characterization of isolation-bydistance processes using dominant genetic markers. Mol. Ecol. 12: 1577-1588. https://doi.org/10.1046/j.1365294X.2003.01835.x

Hardy OJ and Vekemans X (2002). SPAGeDi: a versatile computer program to analyse spatial genetic structure at the individual or population levels. Mol. Ecol. 2: 618-620. https://doi.org/10.1046/j.1471-8286.2002.00305.x

Hardy OJ, Maggia L, Bandou E, Breyne P, et al. (2006). Fine-scale genetic structure and gene dispersal inferences in 10 neotropical tree species. Mol. Ecol. 15: 559-571. https://doi.org/10.1111/j.1365-294X.2005.02785.x

IDEMA (2010). Anuário Estatístico do Rio Grande do Norte. Natal, 37: 1-348.

Kageyama PY, Gandara FB and Souza LMI (1998). Consequências genéticas da fragmentação sobre populações de espécies arbóreas. Série Técnica IPEF 12: 65-70.

Leitman P, Soares K, Henderson A, Noblick L, et al. (2015). Arecaceae in Lista de Espécies da Flora do Brasil. Jardim Botânico do Rio de Janeiro. Available at [http://floradobrasil.jbrj.gov.br/jabot/floradobrasil/FB53]. Accessed June, 2017.

Lowe AJ, Boshier D, Ward M, Bacles CFE, et al. (2005). Genetic resource impacts of habitat loss and degradation; reconciling empirical evidence and predicted theory for neotropical trees. Heredity (Edinb) 95: 255-273. https://doi. org/10.1038/sj.hdy.6800725

Melo Júnior AF, Carvalho D, Brandão MM, Sousa LG, et al. (2015). Spatial genetic structure of Cavanillesia arborea K. Schum. (Malvaceae) in seasonally dry Tropical forest: Implications for conservation. Biochem. Syst. Ecol. 58: 114119. https://doi.org/10.1016/j.bse.2014.11.004

$\mathrm{Ng} \mathrm{KK}$, Lee SL and Koh CL (2004). Spatial structure and genetic diversity of two tropical tree species with contrasting breeding systems and different ploidy levels. Mol. Ecol. 13: 657-669. https://doi.org/10.1046/j.1365$\underline{294 X .2004 .02094 . x}$

Genetics and Molecular Research 16 (3): gmr16039768 
Oliveira MSP, Santos JB, Amorim EP and Ferreira DF (2010). Variabilidade genética entre acessos de açaizeiro utilizando marcadores microssatélites. Cienc. Agrotec. 34: 1253-1260. https://doi.org/10.1590/S1413-70542010000500025

Reis RGE, Pereira MS, Gonçalves NR, Pereira DS, et al. (2011). Emergência e qualidade de mudas de Copernicia prunifera em função da embebição das sementes e sombreamento. Rev. Caatinga 24: 43-49.

Rossi FS, Rossi AAB, Dardengo JFE, Brauwers LR, et al. (2014). Diversidade genética em populações naturais de Mauritia flexuosa L. f. (Arecaceae) com uso de marcadores ISSR. Sci. For. 42: 631-639.

Silva MS, Vieira FA and Carvalho D (2011). Diversity and genetic structure in natural populations of Geonoma schottiana Mart (Arecaceae): implications for conservation. Cerne 17: 95-201. https://doi.org/10.1590/S0104$\underline{77602011000200006}$

Silva RAR, Sousa RF, Araújo LHB, Pinheiro LG, et al. (2014). Distribuição espacial em microescala da palmeira carnaúba, Copernicia prunifera (Mill) H. E. Moore. ACSA 10: 118-121.

Vieira FA and Carvalho D (2008). Genetic structure of an insect-pollinated and bird-dispersed tropical tree in vegetation fragments and corridors: implications for conservation. Biol. Conserv. 17: 2305-2321.

Vieira FA, de Carvalho D, Higuchi P, Machado EL, et al. (2010). Spatial pattern and fine-scale genetic structure indicating recent colonization of the palm Euterpe edulis in a Brazilian Atlantic forest fragment. Biochem. Genet. 48: 96-103. https://doi.org/10.1007/s10528-009-9298-3

Vieira FA, Fajardo CG, Souza AM, Reis CAF, et al. (2012). Fine-scale genetic dynamics of a dominant neotropical tree in the threatened Brazilian Atlantic Rainforest. Tree Genet. Genomes 8: 1191-1201. https://doi.org/10.1007/s11295012-0506-7

Vieira FA, Sousa RF, Silva RAR, Fajardo CG, et al. (2015). Diversidade genética de Copernicia prunifera com o uso de marcadores moleculares ISSR. Agraria 10: 525-531. https://doi.org/10.5039/agraria.v10i4a5040

Wiegand T and Moloney KA (2004). Rings, circles, and null-models for point pattern analysis in ecology. Oikos 104: 209229. https://doi.org/10.1111/j.0030-1299.2004.12497.x

Yeh FC, Yang RC, Boyle TBJ, Ye ZH, et al. (1997). POPGENE, the user-friendly shareware for population genetic analysis molecular biology and biotechnology center. Molecular Biology and Biotechnology Center, University of Alberta, Edmonton, Alberta, Canada.

Genetics and Molecular Research 16 (3): gmr16039768 